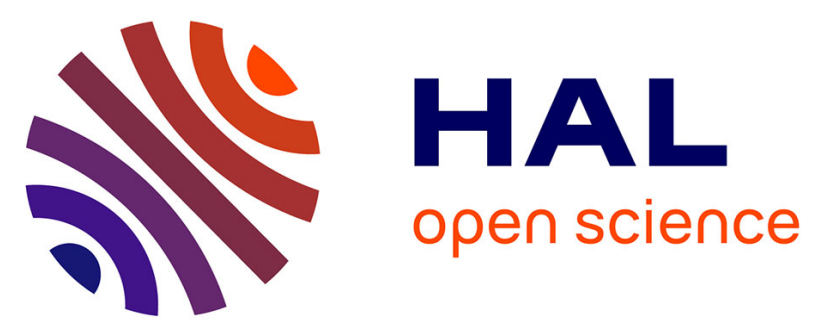

\title{
Performance of a new rapid diagnostic test the lactate/glucose ratio of synovial fluid for the diagnosis of septic arthritis
}

Pascal Guggenbuhl, Olivia Berthoud, Guillaume Coiffier, Jean-David Albert, Anne Gougeon-Jolivet, Claire Goussault, Claude Bendavid

\section{To cite this version:}

Pascal Guggenbuhl, Olivia Berthoud, Guillaume Coiffier, Jean-David Albert, Anne Gougeon-Jolivet, et al.. Performance of a new rapid diagnostic test the lactate/glucose ratio of synovial fluid for the diagnosis of septic arthritis. Joint Bone Spine, 2020, 87 (4), pp.343-350. 10.1016/j.jbspin.2020.03.009 . hal-02563465

\section{HAL Id: hal-02563465 \\ https://hal-univ-rennes1.archives-ouvertes.fr/hal-02563465}

Submitted on 19 May 2020

HAL is a multi-disciplinary open access archive for the deposit and dissemination of scientific research documents, whether they are published or not. The documents may come from teaching and research institutions in France or abroad, or from public or private research centers.
L'archive ouverte pluridisciplinaire HAL, est destinée au dépôt et à la diffusion de documents scientifiques de niveau recherche, publiés ou non, émanant des établissements d'enseignement et de recherche français ou étrangers, des laboratoires publics ou privés. 
Performance of a new rapid diagnostic test the lactate/glucose ratio of synovial fluid for the diagnosis of septic arthritis.

Olivia Berthoud a , Guillaume.Coiffier a,b, Jean-David Albert a,b, Anne Gougeon-Jolivet ${ }^{\mathrm{b}, \mathrm{c}}$, Claire Goussault a, Claude Bendavid d,e, Pascal Guggenbhula,b

aDepartment of Rheumatology, Rennes University Hospital - Pontchaillou, 2 Rue Henri Le Guilloux, 35000, Rennes, France.

bUMR INSERM U 1241, University of Rennes, Rennes, France

cBacteriology Laboratory, Rennes University Hospital - Pontchaillou, 2 Rue Henri Le Guilloux, 35000, Rennes, France.

dDepartment of Biochemistry, Rennes University Hospital - Pontchaillou, 2 Rue Henri Le Guilloux, 35000, Rennes, France.

eINSERM Unité Mixte de Recherche 991, F-35043 Rennes, France

Corresponding author : Olivia Berthoud

olivia.berthoud@chu-rennes.fr

Highlights:

- $\quad$-Septic arthritis is a diagnostic emergency. However, this diagnosis is not evident among all acute arthritis.

- $\quad$-In this cross-sectional study, that included 233 acute arthritis, lactate levels were higher in the septic group. The AUC of lactate was 0.795 .

- - Glucose levels were lower in the septic group and the AUC of glucose was 0.833 . Lactate/Glucose ratio AUC was 0.859 .

- $\quad$-These synovial markers allow septic arthritis to be distinguished more quickly than culture from other acute arthritis.

02.99.26.71.40 


\begin{abstract}
:
Objective: To evaluate the diagnostic performance of the synovial lactate, glucose and lactate/glucose ratio assay for the diagnosis of septic arthritis.

Methods: In this monocentric cross-sectional study, synovial fluids were prospectively obtained from patients with acute joint effusion ( $<30$ days) on native joint. Septic arthritis was defined using Newman's criteria. To evaluate diagnostic performance, Receiver Operating Characteristic (ROC) curves with Area under the curve (AUC), Sensitivities (Se), Specificities (Sp), LR+ their 95\% confidence intervals were calculated. Synovial fluid cultures with gram staining, crystal analyses, synovial fluid white blood cell counts (WBC), lactate and glucose assays were performed.
\end{abstract}

Results: A total of 233 synovial fluids were included. 25 patients had septic arthritis and 208 had non-septic arthritis (104 crystal-induced arthritis, 15 RA, 8 SpA, 6 reactive arthritis, and 75 acute arthritis of undifferentiated origin). Synovial lactate/glucose ratio performed higher than the synovial lactate or glucose assay separately (AUC: 0.859 [0.772-0.945]). Best synovial lactate/glucose ratio threshold to differentiate septic arthritis from non-septic arthritis was 5 Se 52\% [0.34-0.7], Sp 98.1\% [0.95-0.99], LR+ 27.0[9.50-76.00]).

Conclusion: The diagnostic performance of synovial lactate/glucose allows septic arthritis to be effectively and very quickly distinguished from other types of arthritis.

\title{
Keywords:
}

Septic arthritis

glucose

synovial fluid

Ratio lactate/glucose

lactate

acute arthritis

\section{Introduction}

Septic arthritis is a medical emergency, as only prompt and effective antibiotic treatment can lessen the high risk of life-threatening sepsis and function-threatening joint destruction(1-6). Differentiating septic arthritis from other types of acute inflammatory arthritis can be challenging given similarities in clinical and laboratory appearance(79). Even though they are the essential means to identify a pathogen, synovial fluid cultures are time-consuming and consequently targeted antibiotic treatment are delayed(10). Gram staining is a fast, but not very efficient method with only 45 to $50 \%$ of sensitivity to detect bacterial infection(4,11-13). The synovial fluid culture can be negative in $20 \%$ of cases, and can take up to 72 hours.

The identification of a synovial biomarker to be available in daily clinical practice appears useful to discriminate septic arthritis more quickly and improve its management. Many markers such as white blood cell count, percentage of polymorphonuclear cells, Inter-leukine 6 and procalcitonin in synovial fluid have been investigated without reaching any consensus on diagnostic utility(13-20)

However, bacterial metabolism is well studied. Thus, it is shown that the presence of a bacterium generates glucose consumption and consequently lactic acid production. Lactate and glucose as diagnostic biomarkers have been known for many years. After being forgotten between 1970s and 2000, their study raises scientific interest(21). These markers are used in particular for the diagnosis of bacterial meningitis with good diagnostic performance(22). In the diagnosis of septic arthritis, their use could also allow earlier diagnosis than standard culture(23-25). To overcome the time constraint, rapid assessment techniques, namely the use of glucometers and urine strips directly on the synovial fluid, were evaluated(26-28).

The primary objective of this study was to evaluate the clinical relevance and diagnostic performance of lactate and glucose concentration measurement in acute arthritis synovial fluid. The secondary objectives were to evaluate the practical interest and diagnostic performance of the urine test strip and glucometer in synovial fluid. 


\section{Methods}

\section{2-1-Study design and population.}

A monocentric cross-sectional study was conducted during 01/21/2015 to 06/30/2018, in the rheumatology department of the University hospital in Rennes, France. The synovial fluids were prospectively collected in our rheumatology department (SYNOLACTATE Cohorte). The inclusion criteria were: age $>18$ years, acute joint effusion on a native joint, atraumatic, evolving for less than 30 days. Approval for this study was obtained from our institution's ethical committee. (Notification:16.96)

\section{2-2 Study protocol and measurements.}

Synovial fluids were obtained by arthrocentesis. The following tests were performed: Synovial fluid culture with gram staining, crystal analysis, synovial fluid white blood cell count (WBC), percentage of polynuclear neutrophil cells, lactate and glucose. From 05/20/2016, two urine strips were performed using the same Combur10® UX strips using Urisys $1100 \otimes$ Urine Analyzer ( $F$. Hoffmann-La Roche AG, Basel, Switzerland) on the synovial fluid. Then from 12/28/2017, an analysis by glucometer (Accu-Chek® performa) on synovial fluid. The determination of glucose and lactate was performed using the biochemical laboratory technique.

\section{2-3 Diagnoses and case definitions in the study.}

Septic arthritis was defined according to Newman's criteria(2) and synovial fluid analysis when one of the three following results was found: 1) a pathogen was isolated from synovial fluid; 2) a pathogen was isolated from blood culture with typical clinical presentation for septic arthritis; 3) arthrocentesis revealed purulent synovial fluid in combination with presence typical clinical presentation for septic arthritis, absence of crystals and absence of other suitable diagnoses. In some cases, we considered the possibility of a bacterial contamination when the situation was not matching septic etiology and the bacterium was not pathogenic (i.e. Cutibacterium acnes, Coagulasenegative Staphylococcus, Corynebacterium sp.). In these cases, we have considered synovial fluids as non-septic when a favorable clinical, biological and radiographic evolution was observed without antibiotic therapy.

Other diagnoses were considered based on the presence or absence of crystals on polarized light microscopy assessment. In the absence of crystals, an immunological assessment was performed (anti-cyclic citrullinated peptide antibodies (anti CCP), rheumatoid factors (RF) and anti-nuclear antibodies (ANA)). 2010 ACR/EULAR criteria(29) were used to classify rheumatoid arthritis (RA) patients. ASAS criteria(30) were used to classify axial and/or peripheral spondylarthritis (SpA) patients. Reactive arthritis was diagnosed as a non-septic arthritis occurring in the month following urethral or enteroinvasive infection (Chlamydia sp., Yersinia sp., Campylobacter sp....). Crystal-induced arthritis was defined by the presence of urate monosodic crystals (Gout-arthritis) or with a calcium pyrophosphate crystal (CPP arthritis), negative bacteriological culture and favorable evolution under adapted treatment.

The final diagnosis was assessed by the clinician in charge of the patient.

\subsection{Statistical analysis.}

Statistical analysis was performed with SPSS 20.0. $P<0.05$ was considered significant.

The continuous quantitative variables were expressed as mean \pm standard deviation or median \pm interquartile deviation (IQR), after checking their Gaussian distribution or not. The variables selected as Gaussian in our population were: age, synovial glucose dosage per glucometer and mean corticosteroid dose. The other variables were of non-Gaussian distribution according to Kolmogorov-Smirnov test. The comparison of these variables (with $k$ the number of variables group) was performed by a Student t test (verified Gaussian distribution), a Mann-Whitney nonparametric $\mathrm{U}$ test $(\mathrm{k}=2)$ or a Kruskal-Wallis test $(\mathrm{k}>2)$ (non-Gaussian distribution). The qualitative variables were expressed in absolute number and percentage and their comparison was made by a chi-2 test $(\chi)$ or the exact Fisher test if one of the theoretical numbers in the contingency table was less than 5 . For $k>2$ qualitative variables, an adjustment with Bonferroni method was performed. All missing data were considered negative. 
For diagnostic performance, Receiver Operating Characteristic (ROC) curves with Area under the curve (AUC), Sensitivities (Se), Specificities (Sp), LR+, LR- and their $95 \%$ confidence intervals were performed Contingency tables were also produced with calculation of the agreement. The correlation between 2 quantitative variables was studied by the Spearman rho calculation.

\section{Results}

\subsection{Characteristics of the population studied}

Among the 251 synovial fluids examined, 18 were excluded: 12 because SFWBC was $<2000 / \mathrm{mm} 3$ (osteoarthritis), 4 because if incomplete record, 1 was not a native joint arthritis, 1 was included 2 times for the similar joint effusion (Figure 1).

We included 233 synovial fluids from 226 patients in the study. For 7 patients we had 2 different synovial fluids. These patients had a mean age of $61.8 \pm 20.2$, and $151(64.8 \%)$ were males. The most punctured joint was the knee $(71.7 \%)$. According to the criteria defined above, 25 patients were considered as cases of septic arthritis and 208 as case of non-septic arthritis.

There were significantly more cases of cirrhosis in the septic group than in the non septic group $(p<0.001)$ but the other clinical comorbidities were comparable among both groups (Table 1). Before the first puncture, $18.5 \%$ of patients had received antibiotic therapy.

Staphylococcus sp. was the most frequently isolated organism in 11 cases. Streptococcus sp. were found in 6 cases, Bacilli gram negative in 5 and 1 was gonococci. In 2 cases, no pathogen was isolated, but the clinician approved the diagnosis as positive.

Among the 208 samples from non-septic arthritis, 104 (50\%) were consistent with crystal-induced arthritis. There were 15 cases of RA, 8 cases of SpA, 6 cases of reactive arthritis, 57 cases of acute arthritis of undifferentiated origin and 18 types of arthritis of rarer causes.

\section{2- Lactate and glucose performance}

The median levels of synovial lactates and lactates/glucose ratio were significantly higher, while the median level of synovial glucose was lower in the septic arthritis group than in the acute non-septic arthritis group (Table1/Figure2). Considering the AUC, diagnostic performance was higher for the lactate/glucose ratio $(0.859$ [0.772-0.945]) than for lactate or synovial levels separately (Figure 3).

Best synovial lactate/glucose ratio threshold to differentiate septic arthritis from non-septic arthritis was 5 Se $52 \%$ [0.34-0.7], Sp 98.1\% [0.95-0.99], LR+ 27.0[9.50-76.00], LR-[0.33-0.74]). (Table 2)

The performance of the other variables is shown in supplementary data [Appendix A, Table S1; See the supplementary material associated with this article online]. By creating contingency tables for lactate, glucose and lactate/glucose ratio, the thresholds for the use of these parameters were defined. (Appendix A, Table S2).

\subsection{False-negative cases results}

Among the 25 septic arthritis (table 3 ), 16 were not well discriminated by glucose and lactate parameters defining false negatives. Among these 16 synovial fluids, we observed 5 gram negative bacilli, 1 Neisseria gonorrhoeae, 8 cocci gram positive including 6 Staphylococcus aureus, 2 Streptococcus sp. and 2 undocumented septic arthritis.

The five-gram negative septic arthritis appeared to have high lactate (between 8.77 and $17.68 \mathrm{mmol} / \mathrm{L}$ ) with no decrease in glucose (not lower than $2 \mathrm{mmol} / \mathrm{L}$ ). There were 5 septic BGN arthritis without decrease in synovial 
glucose level (0 BGN vs 11 Gram positive (64.7\%) for a glucose threshold $<1.8 \mathrm{mmol} / \mathrm{L}, \mathrm{p}=0.035$ ). (Appendix $\mathrm{A}$, Figure S1) Among the false negatives, there were some particularities. In three cases of septic arthritis, the volume of synovial fluid aspirated was lower than $1 \mathrm{ml}$. In two cases of septic arthritis, antibiotic therapy was started before the puncture. In one case, the culture was positive, however there was only a weak inoculum $(<10$ colonies/box $)$

Of the 2 cases of arthritis considered septic without documentation, the first was strongly suspected of being Streptococcus pneumoniae with positive antigenuria. The second one was strongly suspected of being septic in an immunocompromised patient undergoing chemotherapy. The evolution was initially unfavorable with ceftriaxone, secondary favorable with piperacillin-tazobactam and vancomycin therapy.

\subsection{False positive cases results}

Using the lactate/glucose ratio $>5$ derived from our table, there was 4 false positives cases (1 RA, 2 CPP arthritis and 1 gout). Considering the threshold of synovial lactate ( $\geq 10 \mathrm{mmol} / \mathrm{L}$ ), we counted 2 false positives ( both cases were CPP arthritis).Concerning the threshold of synovial glucose $(<1.8 \mathrm{mmol} / \mathrm{L})$, we observed 10 non-septic synovial fluids: 3 CPP arthritis, 1 gout arthritis, 1 RA (with very low glucose at $0.1 \mathrm{mmol} / \mathrm{L}$ ), 2 reactive arthritis and 3 patients with a diagnosis of undifferentiated arthritis. No false positive case was observed with a synovial lactate threshold of $11.5 \mathrm{mmol} / \mathrm{L}$

\subsection{Correlation between measured by glucometer, automated analyzer, and urinary strips}

The correlation between synovial fluid glucose measured by glucometer or automated analyzer $(n=30)$ was very strong with non-parametric Spearman rho $(\rho)=0.933$. The correlation between synovial fluid glucose measurement by the automated analyzer and the urinary strips test $(n=128)$ was moderate with non-parametric Spearman rho $(\rho)=0.589$ (Appendix A, Figure S2). The correlation between strip $n^{\circ} 1$ and $n^{\circ} 2$ was Spearman rho $(\rho)=0.709$.

\section{Discussion}

This study looked at the relevant diagnostic performance of lactate and glucose assay in synovial fluid to discriminate septic arthritis from non-septic arthritis. We have shown that synovial lactate/glucose ratio was relevant in discriminating septic arthritis from other arthritis with a good discriminating performance (AUC > 0.85.LR+ 27.0)

To our knowledge no previous study described synovial lactate/glucose ratio performance. In our study synovial lactate/glucose ratio performance was superior to each isolated component. For an easier comparison of the literature, we propose to compare our results on synovial lactate and glucose successively.

\subsection{Lactates performances}

Many studies have focused on the diagnostic performance of lactate assay since the 1970s. Consistent with our results, in literature the specificity of synovial lactate was excellent ranging from $95 \%$ (cut off at $12 \mathrm{mmol} / \mathrm{L}$ )(31) to $100 \%$ (cut off $\geq 10 \mathrm{mmol} / \mathrm{L}$ )(32) for the diagnosis of septic arthritis. On the other hand,the sensitivity showed a greater variation ranging from $56 \%$ (cut off $\geq 10 \mathrm{mmol} / \mathrm{L}$ )(24) to $100 \%$ (cut off at $12 \mathrm{mmol} / \mathrm{L}$ )(31).

Variations were probably related to different populations in different studies, with many cases of osteoarthritis(3133). We explain our low sensitivity ( $44 \%$ for cut off $\geq 10 \mathrm{mmol} / \mathrm{L}$ ) due to the characteristics of our cohort with very acute arthritis (average evolution of 5 days). This cohort excluded synovial fluids $<2000 / \mathrm{mm} 3$ SFWBC (osteoarthritis) and included many highly inflammatory crystal-induced arthritis in control group. Indeed, for a synovial lactate $\geq 10 \mathrm{mmol} / \mathrm{L}$, we observed 2 false positives with CPP arthritis probably due to the very inflammatory nature of crystal-induced arthritis(34). Some authors explained these high lactate levels by synovial hypoxia( 35,36$)$. Consistent with this point, CRP levels were correlated with lactate levels (Appendix A, Figure S3).This was in the sense that the more inflammatory an arthritis is (suggested by a high CRP), the greater the degree of tissue hypoxia ( suggested by a high synovial lactate). Nevertheless, it should be noted that no non-septic arthritis had a lactate level greater than $11.5 \mathrm{mmol} / \mathrm{L}$ in our study, close to the threshold of $12 \mathrm{mmol} / \mathrm{L}$ already reported in the literature (31). 
Lenski et al.(14) defined a lactate level $<4.3 \mathrm{mmol} / \mathrm{L}$ allowing to rule out septic arthritis. We did not find any value of lactate to classify as non-septic arthritis with a non-clinical pertinence of negative likelihood ratio. However, mechanical synovial fluids (SFWBC < 2000/mm3) were excluded from our study, in order to include only inflammatory synovial fluids.

Finally, our data were close to the AUC reported in recent studies, with lactate performance (AUC 0.864(14) and AUC 0.901 (23)). In our study, the lactate performances were altered by certain bacteria, notably Neisseria sp. which did not led to an increase in lactate levels. This characteristic has long been known for Neisseria gonorrhea arthritis, and is probably due to the strict aerobic mechanism(35,37). Some of these false positives might as well be explained by technical issues. A minimum of $1 \mathrm{ml}$ of synovial fluid was required to perform the assay. However, in particular joints as ankle and wrist it was not always possible to aspirate such a quantity of liquid. Using the lactate/glucose ratio, low volume technical problems with less precise dilutions were neutralized.

\subsection{Glucose performances}

Previously published studies reported on the performance of variable synovial glucose for the diagnosis of septic arthritis (AUC 0.701(14), 0.853(23), and AUC 0.960(26)).

Omar et al.(26) found a cut off of synovial glucose $<1.4 \mathrm{mmol} / \mathrm{L}$ to discriminate septic arthritis with a sensitivity of $100 \%$ and a specificity of $92 \%$. We have not seen such a god performance in our population. Once again, the population studied in this study was very different from ours, with $41 \%$ of osteoarthritis in the control group. As explained before, the hypothesis of tissues the hypothesis of tissue hypoxia may explain the increased lactate, and anaerobic metabolism of synoviocytes might also consume glucose.

In addition, Omar et al. (26) excluded patient treated with antibiotic therapy prior to puncture while it accounted for almost $20 \%$ of our patients. The hypothesis that prior antibiotic therapy could reduce bacterial inoculum and therefore glucose levels could be satisfactory. However, we were unable to show this result due to our small sample of septic arthritis. In our study, gram-negative bacteria infections were associated with synovial lactate increase without glucose lowering. We did not find any similar findings in the literature (i.e Omar et al(26) had no gramnegative bacilli to compare with). One possible explanation is the difference in the carbohydrate metabolism pathway of the bacteria.

So, we showed, in accordance with the positive likelihood ratio, that the more discriminating threshold for septic arthritis in acute arthritis population was $<1.8 \mathrm{mmol} / \mathrm{L}$.

The secondary objectives were to evaluate the practical interest and diagnostic performance of the urine test strip and glucometer in synovial fluid. The correlation of glucose values measured by the glucometer and measured by the automaton was very strong (Spearman rho $(\rho)=0.933$ ). This result confirmed the excellent correlation for fast synovial glucose determination in previous studies $(26,28)$. Concerning the urine test strip, the results were less clear cut. These data support the move away from urine strips to more accurate and reproducible use of the glucometer. However, the use of the glucometer might still be impacted by technical difficulties such as hyper viscosity (27).

The first strong point of this study was its methodology, namely a prospective collection including patients who had received antibiotic therapy before the puncture. This was the largest cohort of native joints synovial fluids prospectively collected in the literature. All patients were included in this pragmatic real life study even if some data were missing. In this context, Gram stain was positive in only $16 \%$ of cases, which was lower than expected in the literature(11). Arthritis was punctured early in less than 5 days, which probably explains low bacterial inoculum. Moreover, this result could also possibly be explained by prior antibiotic therapy in $20 \%$ of patients. Our sample was too small to show a possible difference between lactate and glucose levels with or without antibiotic therapy prior to puncture.

Several limitations should potentially be mentioned.1) We observed a small proportion of septic arthritis (10.7\%) compared to the $15 \%$ usually reported(1). It was a choice to include all native arthritis less than 30 days old, without exclusion criteria, but requiring a minimum volume of synovial fluid for full analysis. Septic arthritis in small joints 
with a low volume of synovial fluid could not be included, possibly explaining our prevalence. 2) We found several cases of very high glucose levels which cannot be explained by the $10 \%$ of diabetics alone. We used the same analytical process as described in the other study (26) but we did not compare synovial glucose levels with capillary blood sugar. 3) Our technique only allowed the determination of L-Lactate $(25,38,39)$. However, it is known that some bacteria produce $\mathrm{D}$-Lactate rather than L-Lactate. This could explain some of the relatively low lactate levels. Nevertheless, this explanation must be considered with caution because, in our study, we had few false negatives with lactate, and many more with glucose and especially gram-negative bacilli.

In conclusion, the diagnostic performance of glucose and lactate was good for discriminating septic arthritis from others in population with very acute arthritis, especially using the lactate/glucose ratio.

\section{Appendix A. Supplementary data}

Supplementary data (Table S1-S2, Fig. S1-S3) associated with this article can be found in the online version at ...

Disclosure : None of the autors received payments or services, either directly or indirectly (via his institution), from a third party in support any aspect of this work. None of the autors received payments or services, either directly or indirectly (via his institution), from a third party in support any aspect of this work. This research did not receive any specific grant from funding agencies in the public, commercial, or not-for-profit sectors. 


\section{References}

1. Gupta MN, Sturrock RD, Field M. A prospective 2-year study of 75 patients with adult-onset septic arthritis. Rheumatology. 2001;40(1):24-30.

2. Newman JH. Review of septic arthritis throughout the antibiotic era. Ann Rheum Dis. 1976;35(3):198205.

3. Kaandorp CJ, Krijnen P, Moens HJ, Habbema JD, van Schaardenburg D. The outcome of bacterial arthritis: a prospective community-based study. Arthritis Rheum. 1997;40(5):884-92.

4. Weston VC, Jones AC, Bradbury N, Fawthrop F, Doherty M. Clinical features and outcome of septic arthritis in a single UK Health District 1982-1991. Ann Rheum Dis. 1999;58(4):214-9.

5. Hassan AS, Rao A, Manadan AM, Block JA. Peripheral Bacterial Septic Arthritis: Review of Diagnosis and Management. JCR J Clin Rheumatol. 2017;23(8):435-42.

6. Mathews CJ, Weston VC, Jones A, Field M, Coakley G. Bacterial septic arthritis in adults. Lancet Lond Engl. 2010;375(9717):846-55.

7. Ward PCJ. Interpretation of synovial fluid data. Postgrad Med. 1980 Sep 1;68(3):175-84.

8. Pavic K, Pandya J, Sebak S, Shetty A, Spencer D, Manolios NN. Acute arthritis: predictive factors and current practice in the approach to diagnosis and management across two hospitals in Sydney. Intern Med J. 2018;48:1087-95.

9. Prior-Español Á, García-Mira Y, Mínguez S, Martínez-Morillo M, Gifre L, Mateo L. Coexistence of septic and crystal-induced arthritis: A diagnostic challenge. A report of 25 cases. Reumatol Clin. $2019 ; 15: e 81-5$

10. Balderia PG, Pomerantz S, Fischer R. Acute bacterial arthritis: how long should you wait for culture results? J Clin Rheumatol Pract Rep Rheum Musculoskelet Dis. 2015;21(4):196-8.

11. Faraj AA, Omonbude OD, Godwin P. Gram staining in the diagnosis of acute septic arthritis. Acta Orthop Belg. 2002;68(4):388-91.

12. Stirling $P$, Tahir M, Atkinson HD. The limitations of Gram-stain microscopy of synovial fluid in concomitant septic and crystal arthritis. Curr Rheumatol Rev. 2018;255-7.

13. McGillicuddy DC, Shah KH, Friedberg RP, Nathanson LA, Edlow JA. How sensitive is the synovial fluid white blood cell count in diagnosing septic arthritis? Am J Emerg Med. 2007;25(7):749-52.

14. Lenski M, Scherer MA. The significance of interleukin-6 and lactate in the synovial fluid for diagnosing native septic arthritis. Acta Orthop Belg. 2014;80(1):18-25.

15. Ferreyra M, Coiffier G, Albert J-D, David C, Perdriger A, Guggenbuhl P. Combining cytology and microcrystal detection in nonpurulent joint fluid benefits the diagnosis of septic arthritis. Jt Bone Spine Rev Rhum. 2017;84(1):65-70.

16. Shmerling RH, Delbanco TL, Tosteson AN, Trentham DE. Synovial fluid tests. What should be ordered? JAMA. 1990;264(8):1009-14.

17. Carpenter CR, Schuur JD, Everett WW, Pines JM. Evidence-based Diagnostics: Adult Septic Arthritis. Acad Emerg Med Off J Soc Acad Emerg Med. 2011;18(8):781-96.

18. Talebi-Taher M, Shirani F, Nikanjam N, Shekarabi M. Septic versus inflammatory arthritis: discriminating the ability of serum inflammatory markers. Rheumatol Int. $2013 ; 33(2): 319-24$. 
19. Saeed K, Dryden M, Sitjar A, White G. Measuring synovial fluid procalcitonin levels in distinguishing cases of septic arthritis, including prosthetic joints, from other causes of arthritis and aseptic loosening. Infection. $2013 ; 41(4): 845-9$.

20. Wang C, Zhong DA, Liao Q, Kong L, Liu A, Xiao H. Procalcitonin levels in fresh serum and fresh synovial fluid for the differential diagnosis of knee septic arthritis from rheumatoid arthritis, osteoarthritis and gouty arthritis. Exp Ther Med. 2014;8(4):1075-80.

21. Kopterides P. Synovial lactic acid and septic arthritis. JAMA. 2007 Jul 4;298(1):40; author reply 40.

22. Reimer LG. Approach to the analysis of body fluids for the detection of infection. Clin Lab Med. 1985;5(2):209-222.

23. Lenski M, Scherer MA. Analysis of synovial inflammatory markers to differ infectious from gouty arthritis. Clin Biochem. 2014;47(1-2):49-55.

24. Brook I. The importance of lactic acid levels in body fluids in the detection of bacterial infections. Rev Infect Dis. 1981;3(3):470-8.

25. Marcos MA, Vila J, Gratacos J, Brancos MA, Jimenez de Anta MT. Determination of D-lactate concentration for rapid diagnosis of bacterial infections of body fluids. Eur J Clin Microbiol Infect Dis Off Publ Eur Soc Clin Microbiol. 1991;10(11):966-9.

26. Omar M, Reichling M, Liodakis E, Ettinger M, Guenther D, Decker S, et al. Rapid exclusion of bacterial arthritis using a glucometer. Clin Rheumatol. 2017;36(3):591-8.

27. Coiffier G, Pollet S, Albert J-D, Perdriger A, Guggenbuhl P, Chales G. Usefulness and limitations of rapid urine dipstick testing for joint-fluid analysis. Prospective single-center study of 98 specimens. Jt Bone Spine Rev Rhum. 2013;80(6):604-7.

28. Omar M, Ettinger M, Reichling M, Petri M, Lichtinghagen R, Guenther D, et al. Preliminary results of a new test for rapid diagnosis of septic arthritis with use of leukocyte esterase and glucose reagent strips. J Bone Joint Surg Am. 2014;96(24):2032-7.

29. Aletaha D, Neogi T, Silman AJ, Funovits J, Felson DT, Bingham CO, et al. 2010 Rheumatoid arthritis classification criteria: an American College of Rheumatology/European League Against Rheumatism collaborative initiative. Arthritis Rheum. 2010;62(9):2569-81.

30. Sieper J, Rudwaleit M, Baraliakos X, Brandt J, Braun J, Burgos-Vargas R, et al. The Assessment of SpondyloArthritis international Society (ASAS) handbook: a guide to assess spondyloarthritis. Ann Rheum Dis. 2009;68 Suppl 2:ii1-44.

31. Riordan T, Doyle D, Tabaqchali S. Synovial fluid lactic acid measurement in the diagnosis and management of septic arthritis. J Clin Pathol. 1982;35(4):390-4.

32. Mossman SS, Coleman JM, Gow PJ. Synovial fluid lactic acid in septic arthritis. N Z Med J 1981;93(678):115-7.

33. Brook I, Reza MJ, Bricknell KS, Bluestone R, Finegold SM. Synovial fluid lactic acid. A diagnostic aid in septic arthritis. Arthritis Rheum. $1978 ; 21(7): 774-9$.

34. Gerster JC, Gobelet C. Synovial fluid lactic acid in acute and chronic pyrophosphate arthropathy and in osteoarthritis. Clin Rheumatol. 1988 ;7(2):197-9.

35. Riley TV. Synovial fluid lactic acid levels in septic arthritis. Pathology (Phila). $1981 ; 13(1): 69-71$.

36. James MJ, Cleland LG, Rofe AM. Determinants of synovial fluid lactate concentration. J Rheumatol. 1992 ;19(7):1107-10. 
37. Kirwan JR. Synovial fluid lactate in sep1. Gupta MN, Sturrock RD, Field M. A prospective 2-year study of 75 patients with adult-onset septic arthritis. Rheumatology. $2001 ; 40(1): 24-30$.

38. Kortekangas P, Peltola $\mathrm{O}$, Toivanen A, Aro HT. Synovial fluid L-lactic acid in acute arthritis of the adult knee joint. Scand J Rheumatol. 1995;24(2):98-101.

39. Smith SM, Eng RH, Campos JM, Chmel H. D-lactic acid measurements in the diagnosis of bacterial infections. J Clin Microbiol. 1989 ;27(3):385-8.

tic arthritis. Lancet Lond Engl. 1982 Feb 20;1(8269):457.

38. Kortekangas $\mathrm{P}$, Peltola $\mathrm{O}$, Toivanen A, Aro HT. Synovial fluid L-lactic acid in acute arthritis of the adult knee joint. Scand J Rheumatol. 1995;24(2):98-101.

39. Smith SM, Eng RH, Campos JM, Chmel H. D-lactic acid measurements in the diagnosis of bacterial infections. J Clin Microbiol. 1989 ;27(3):385-8. 
Figure 1. Flow chart of the synovial fluids included in the study

Figure 2. Receiver Operating Characteristic (ROC) curves.

ROC curves and corresponding Area under the curve (AUC) of markers for differing between septic arthritis and acute arthritis. An AUC close to 1.0 indicates high sensitivity and specificity.

Synovial lactate (AUC: 0.795 ). Synovial lactate/glucose ratio: (AUC : 0.859). Synovial Glucose (AUC :0.833)

Figure 3. Scatter plots. Levels of lactate (A), glucose (B) and lactate/glucose ratio (C) in septic arthritis, crystal induced arthritis and "Nonon" arthritis.

Scatter plots. Comparison of synovial lactates levels, glucose levels and lactate/glucose ratio between septic arthritis, crystals induced-arthritis and non-septic non crystals induced-arthritis ("no-no" arthritis). The dotted horizontal line indicates the cut off chosen for each parameter. 
Table 1. Characteristics of the 233 acute arthritis with synovial fluid analysis included in the study with comparison between septic arthritis $(n=25)$ and non-septic arthritis $(n=208)$.

\begin{tabular}{|c|c|c|c|c|}
\hline & $\begin{array}{c}\text { Overall population } \\
n=233\end{array}$ & $\begin{array}{c}\text { Septic arthritis } \\
n=25\end{array}$ & $\begin{array}{c}\text { Non-Septic arthritis } \\
n=208\end{array}$ & $p$ \\
\hline Age (years $\pm S D$ ) & $61.8 \pm 20.2$ & $64.0 \pm 20.2$ & $61.6 \pm 20.2$ & 0.57 \\
\hline \multirow{2}{*}{\multicolumn{5}{|c|}{ comorbidities }} \\
\hline & & & & \\
\hline Immunosuppression & $80(34.3)$ & $5(20.0)$ & $75(36.1)$ & 0.11 \\
\hline Hepatic cirrhosis & $67(28.8)$ & $8(32.0)$ & $59(28.4)$ & $\begin{array}{l}0.70 \\
<0.001\end{array}$ \\
\hline Diabetes & $\begin{array}{r}5(2.1) \\
24(10.3)\end{array}$ & $\begin{array}{r}4(16.0) \\
2(8.0)\end{array}$ & $\begin{array}{r}1(0.5) \\
22(10.6)\end{array}$ & 0.90 \\
\hline Organ transplant & $\begin{array}{r}24(10.3) \\
5(2.1)\end{array}$ & $1(4.0)$ & $4(1.9)$ & 0.50 \\
\hline evolutionary cancer & $9(3.9)$ & $2(8.0)$ & $7(3.4)$ & 0.25 \\
\hline & $1(0.4)$ & 0 & $1(0.5)$ & 0.90 \\
\hline DMARDs & $24(10.3)$ & $2(8.0)$ & $22(10.6)$ & 0.90 \\
\hline Biologics & $5(2.1)$ & $1(4.0)$ & $4(1.9)$ & 0.50 \\
\hline chemotherapy & $6(2.6)$ & $1(4.0)$ & $5(2.4)$ & 0.50 \\
\hline $\begin{array}{l}\text { Glucocorticoids } \\
\text { medium dose }(\mathrm{mg} / \mathrm{d} \pm \mathrm{SD})\end{array}$ & $\begin{array}{r}32(13.7) \\
147+39\end{array}$ & 0 & $32(15.4)$ & 0.03 \\
\hline \multicolumn{5}{|l|}{ clinical signs } \\
\hline $\begin{array}{l}\text { Duration of symptoms } \\
\text { number of joints }\end{array}$ & $5.0[3.0-10.0]$ & $6.0[2.0-14.0]$ & $5.0[3.0-10.0]$ & 0.91 \\
\hline Mono & $159(68.2)$ & $19(76.0)$ & $140(67.3)$ & ns \\
\hline Oligo & $51(24.5)$ & $6(24.0)$ & $45(21.6)$ & ns \\
\hline \multicolumn{5}{|l|}{ affected joint } \\
\hline Knee & $167(71.7)$ & $14(56.0)$ & & \\
\hline Ankle & $13(5.6)$ & $2(8.0)$ & $\begin{array}{r}153(73.6) \\
11(5.3)\end{array}$ & $\begin{array}{l}\text { ns } \\
\text { ns }\end{array}$ \\
\hline Hip & $17(7.3)$ & $3(12.0)$ & $14(6.7)$ & ns \\
\hline Shoulder & $16(6.8)$ & $3(12.0)$ & $13(6.3)$ & ns \\
\hline Elbow & $16(6.8)$ & 0 & $16(7.7)$ & ns \\
\hline Wrist & $5(1.7)$ & $3(12.0)$ & $1(0.5)$ & $<0.05$ \\
\hline Fiever & $87(37.3)$ & $17(68.0)$ & $70(33.7)$ & 0.001 \\
\hline Antibiotic treatment $(<10$ days $)$ & $43(18.5)$ & $9(36.0)$ & $34(16.3)$ & 0.02 \\
\hline NSAID therapy $(<15$ days & $25(10.7)$ & $4(16.0)$ & $21(10.1)$ & 0.37 \\
\hline \multicolumn{5}{|l|}{ Blood test } \\
\hline $\begin{array}{l}\text { CRP } \\
\text { Positive Blood Culture }\end{array}$ & $82.8[35.3-153.8]$ & 188.3 [88.8-288.6] & 76.7 [29.8-132.5] & $<0.001$ \\
\hline Synovial fluid & $15(7.7)$ & $7(28.0)$ & $8(4.7)$ & $<0.001$ \\
\hline \multicolumn{5}{|l|}{ Macroscopy $(n=205)$} \\
\hline Purulent & $26(127)$ & $16(667)$ & $10(5.5) \mathrm{r}$ & $<0,05$ \\
\hline Turbid & $125(61.0)$ & $5(20.8)$ & $120(79.5)$ & $<0.05$ \\
\hline Yellow and transparent & $37(18.0)$ & $2(8.3)$ & $35(19.3)$ & ns \\
\hline \multicolumn{5}{|l|}{ Microscopy } \\
\hline $\mathrm{SF}$ WBC $\left(/ \mathrm{mm}^{3}\right)$ & $16500[6050-49000]$ & $79000[15000-117000]$ & 13900 [5400-43000] & $<0.001$ \\
\hline $\mathrm{EN}>50000 / \mathrm{mm}^{3}$ & $52(22.3)$ & $13(52.0)$ & $\begin{array}{r}13900[040-43000] \\
39(18.8)\end{array}$ & $<0.001$ \\
\hline polynuclear neutrophil (\%) & 87.0 [72.5-92.0] & $90.5[83.8-94.0]$ & $86.0[67.0-92.0]$ & 0.002 \\
\hline $\mathrm{PNN}>90 \%$ & $81(34.7)$ & $13(52.0)$ & $68(29.2)$ & 0.03 \\
\hline $\begin{array}{l}\text { microcrystals } \\
\text { Microbiology }\end{array}$ & $108(46.3)$ & $4(16.0)$ & $104(50.0)$ & 0.001 \\
\hline gram stain & $4(17)$ & $4(160)$ & & $<0,001$ \\
\hline \multicolumn{4}{|l|}{ Biochemistry } & $<0.001$ \\
\hline Synovial glucose (mmol/L) & & & $57[46.70]$ & \\
\hline Synovial lactate (mmol/L) & $\begin{array}{l}5.5[4.0-1.0] \\
4.0[2.8-5.9]\end{array}$ & $\begin{array}{l}2.2[0.68-4.3] \\
9.3[4.4-16.3]\end{array}$ & $\begin{array}{l}5.7[4.6-7.0] \\
3.7[2.7-5.5]\end{array}$ & $<0.001$ \\
\hline Ratio Lactates/glucose & $0.67[0.41-1.27]$ & $3.7[1.2-24.7]$ & 0.60 [0.39-1.09] & $<0.001$ \\
\hline \multicolumn{5}{|l|}{ Urine strip $(n=129)$} \\
\hline Glucose deficiency & $22(17.1)$ & $10(76.9)$ & $12(10.3)$ & $p<0.05$ \\
\hline Glucose content & $97(75.2)$ & $3(23.1)$ & $94(81.0)$ & $p<0.05$ \\
\hline uncertain & $10(7.8)$ & 0 & $10(8.6)$ & ns \\
\hline
\end{tabular}


Table 2. Performance of glucose, lactates and lactates/glucose ratio in synovial fluid for diagnosis of septic arthritis.

\begin{tabular}{|c|c|c|c|c|c|c|}
\hline & AUC (Cl95\%) & Cut-off & $\mathrm{Se}(\mathrm{Cl} 95 \%)$ & Sp (CI95\%) & LR+ (Cl95\%) & LR- (CI95\%) \\
\hline $\begin{array}{l}\text { Glucose } \\
\text { (mmol/L) }\end{array}$ & $\begin{array}{l}0.833(0.735- \\
0.931)\end{array}$ & $\begin{array}{l}\leq 1.0 \\
\leq 1.4 \\
\leq 1.8\end{array}$ & $\begin{array}{l}32 \%(0.17- \\
0.52) \\
36 \%(0.20- \\
0.55) \\
44 \%(0.27- \\
0.63)\end{array}$ & $\begin{array}{l}99.0 \%(0.97-1.0) \\
97.1 \%(0.94-0.99) \\
95.2 \%(0.91-0.97)\end{array}$ & $\begin{array}{l}33.3(7.5-148) \\
12.5(4.8-32) \\
15.6(5.6-43)\end{array}$ & $\begin{array}{l}0.69(0.53- \\
0.90) \\
0.66(0.49- \\
0.89) \\
0.59(0.42- \\
0.83)\end{array}$ \\
\hline $\begin{array}{l}\text { Lactates } \\
\text { (mmol/L) }\end{array}$ & $\begin{array}{l}0.795(0.681- \\
0.910)\end{array}$ & $\begin{array}{l}\geq 11.0 \\
\geq 10.0 \\
\geq 9.5 \\
\geq 8.5 \\
<4.3\end{array}$ & $\begin{array}{l}36.0 \%(0.20- \\
0.55) \\
40.0 \%(0.23- \\
0.59) \\
48 \%(0.30- \\
0.67) \\
60 \%(0.41- \\
0.77) \\
76 \%(0.57- \\
0.89)\end{array}$ & $\begin{array}{l}99.5 \%(0.97-1.00) \\
99.0 \%(0.97-1.00) \\
98.1 \%(0.95-0.99) \\
96.6 \%(0.93-0.98) \\
59.6 \%(0.53-0.66)\end{array}$ & $\begin{array}{l}74.9(9.9-566) \\
41.6(9.7-179) \\
25.0(8.7-71) \\
17.8(9.9-63) \\
1.9(1.4-2.5)\end{array}$ & $\begin{array}{l}0.64(0.48- \\
0.86) \\
0.61(0.44- \\
0.84) \\
0.53(0.36- \\
0.77) \\
0.41(0.25- \\
0.66) \\
0.40(0.20- \\
0.82)\end{array}$ \\
\hline Ratio L/Glc & $\begin{array}{l}0.859(0.772- \\
0.945)\end{array}$ & $\begin{array}{l}\geq 5.0 \\
<1\end{array}$ & $\begin{array}{l}52 \%(0.34- \\
0.70) \\
80 \%(0.61- \\
0.91)\end{array}$ & $\begin{array}{l}98.1 \%(0.95-0.99) \\
71.6 \%(0.65-0.77)\end{array}$ & $\begin{array}{l}27.0(9.5-76) \\
2.8(2.1-3.8)\end{array}$ & $\begin{array}{l}0.49(0.33- \\
0.74) \\
0.28(0.13- \\
0.61)\end{array}$ \\
\hline
\end{tabular}

Values in brackets are the corresponding 95\%-confidence intervals. AUC = Area under the curve,

Se: sensitivity, Sp:specificity, $L R+$ :positive likelihood ratio, $L R-:$ negative likelihood ratio 
Table 3. Characteristics of 25 septic arthritis.

\begin{tabular}{|c|c|c|c|c|c|c|c|c|c|c|c|c|c|c|c|c|c|c|}
\hline & $\begin{array}{l}S \\
\text { ex }\end{array}$ & $\begin{array}{l}\text { Yea } \\
\text { rs } \\
\text { (ye } \\
\text { ars) }\end{array}$ & $\begin{array}{l}\text { Joi } \\
\text { nt }\end{array}$ & $\begin{array}{c}\text { Dur } \\
\text { atio } \\
\mathrm{n} \\
\text { (day } \\
\mathrm{s} \text { ) }\end{array}$ & $\begin{array}{l}\text { Fe } \\
\text { ver }\end{array}$ & $\begin{array}{l}\mathrm{A} \\
\mathrm{T} \\
\mathrm{B}\end{array}$ & $\begin{array}{c}\text { CR } \\
P \\
(\mathrm{~m} \\
\mathrm{g} / \mathrm{L} \\
)\end{array}$ & $\begin{array}{c}\mathrm{n}^{\circ} \\
\text { pon } \\
\text { ctio } \\
\mathrm{n}\end{array}$ & $\begin{array}{c}\text { Pur } \\
\text { ulen } \\
t\end{array}$ & $\begin{array}{l}\mathrm{SW} \\
\mathrm{BC} \\
(/ \mathrm{m} \\
\left.\mathrm{m}^{3}\right)\end{array}$ & $\begin{array}{c}P \\
M \\
N \\
(\% \\
)\end{array}$ & $\begin{array}{c}\text { Cry } \\
\text { stal } \\
\mathrm{s}\end{array}$ & $\begin{array}{l}G \\
T\end{array}$ & $\begin{array}{l}\text { Synovi } \\
\text { al Fluid } \\
\text { Culture }\end{array}$ & $\begin{array}{l}\text { Blood } \\
\text { Culture }\end{array}$ & $\begin{array}{c}\text { Glu } \\
\text { cos } \\
e \\
(\mathrm{~mm} \\
\mathrm{ol} / \mathrm{L})\end{array}$ & $\begin{array}{l}\text { Lact } \\
\text { ates } \\
(\mathrm{mm} \\
\mathrm{ol} / \mathrm{L})\end{array}$ & $\begin{array}{c}\text { Ratio } \\
\text { Lact/ } \\
\text { Glc }\end{array}$ \\
\hline 1 & $\mathrm{M}$ & 46 & W & 2 & - & - & $\begin{array}{c}15 \\
7 \\
\end{array}$ & 1 & + & $\begin{array}{l}200 \\
000 \\
\end{array}$ & 95 & - & - & $\begin{array}{l}\text { N.gono } \\
\text { rroeae }\end{array}$ & - & 2.20 & 5.25 & 2.4 \\
\hline 2 & M & 58 & $\mathrm{H}$ & 15 & + & $t^{a}$ & $\begin{array}{c}36 \\
4\end{array}$ & 1 & + & & & - & - & MRSA & MRSA & 0.40 & $\begin{array}{c}27.0 \\
1\end{array}$ & 67.5 \\
\hline 3 & $\mathrm{~F}$ & 59 & K & 2 & + & - & $\begin{array}{c}32 \\
6\end{array}$ & 1 & + & $\begin{array}{c}625 \\
00\end{array}$ & 94 & - & + & $\begin{array}{l}\text { S.pneu } \\
\text { moniae }\end{array}$ & - & 0.70 & $\begin{array}{c}16.1 \\
3\end{array}$ & 23.0 \\
\hline 4 & $\mathrm{M}$ & 59 & $S$ & 8 & + & - & 83 & 1 & - & & 95 & - & - & $M S S A$ & MSSA & 0.10 & $\begin{array}{c}17.2 \\
5\end{array}$ & $\begin{array}{c}172 . \\
5\end{array}$ \\
\hline 5 & M & 33 & A & 7 & + & $+a$ & $\begin{array}{c}48 \\
6 \\
\end{array}$ & 1 & + & & D & - & + & MSSA & - & 0.40 & $\begin{array}{c}24.9 \\
5 \\
\end{array}$ & 62.4 \\
\hline 6 & $M$ & 47 & W & 7 & + & - & 26 & 1 & + & $\Delta$ & & - & - & MSSA & - & 1.20 & 8.73 & 7.3 \\
\hline 7 & $\mathrm{M}$ & 86 & A & 2 & + & - & 92 & 1 & - & $\begin{array}{l}118 \\
000 \\
\end{array}$ & 84 & $\begin{array}{l}\mathrm{CP} \\
\mathrm{P}\end{array}$ & - & $\begin{array}{c}\text { S.gord } \\
\text { onii }\end{array}$ & $\begin{array}{c}\text { S.gord } \\
\text { onii }\end{array}$ & 2.50 & 5.20 & 2.1 \\
\hline 8 & $\mathrm{M}$ & 93 & $S$ & 10 & + & - & $\begin{array}{c}10 \\
3 \\
\end{array}$ & 2 & + & $\begin{array}{l}350 \\
000 \\
\end{array}$ & 77 & - & - & $M S S A$ & MSSA & 7.80 & 7.61 & 1.0 \\
\hline 9 & $\mathrm{M}$ & 91 & $\mathrm{~K}$ & 6 & + & $+c$ & $\begin{array}{c}29 \\
9 \\
\end{array}$ & 2 & - & $\begin{array}{c}120 \\
0 \\
\end{array}$ & 89 & $\begin{array}{l}\mathrm{CP} \\
\mathrm{P}\end{array}$ & - & E.coli & - & 2.70 & 9.68 & 3.6 \\
\hline $\begin{array}{l}1 \\
0 \\
\end{array}$ & $\mathrm{M}$ & 37 & $\mathrm{~K}$ & 13 & + & $+^{d}$ & $\begin{array}{c}16 \\
1 \\
\end{array}$ & 3 & - & $\begin{array}{r}800 \\
00 \\
\end{array}$ & 96 & - & - & MSSA & - & 5.90 & 3.87 & 0.7 \\
\hline $\begin{array}{l}1 \\
1 \\
\end{array}$ & M & 18 & $\mathrm{~K}$ & 1 & + & - & 99 & 2 & - & $\begin{array}{c}160 \\
00 \\
\end{array}$ & 92 & - & - & MSSA & - & 7.00 & 2.50 & 0.4 \\
\hline $\begin{array}{l}1 \\
2 \\
\end{array}$ & $\mathrm{~F}$ & 89 & $\mathrm{~K}$ & 7 & - & $+c$ & $\begin{array}{c}19 \\
5 \\
\end{array}$ & 2 & + & $\begin{array}{r}800 \\
00 \\
\end{array}$ & 92 & $\begin{array}{c}\mathrm{CP} \\
\mathrm{P}\end{array}$ & - & - & E.Coli & 2.50 & 9.33 & 3.7 \\
\hline $\begin{array}{l}1 \\
3\end{array}$ & $\mathrm{M}$ & 79 & $S$ & 21 & - & $\begin{array}{c}+b, \\
e\end{array}$ & 85 & 2 & + & $\begin{array}{c}810 \\
00 \\
\end{array}$ & $\begin{array}{c}10 \\
0 \\
\end{array}$ & - & - & - & - & 4.60 & 2.93 & 0.6 \\
\hline $\begin{array}{l}1 \\
4\end{array}$ & M & 79 & K & 15 & + & $+c$ & $\begin{array}{c}18 \\
9\end{array}$ & 2 & + & $\begin{array}{c}770 \\
0\end{array}$ & 76 & - & - & - & $\begin{array}{l}\text { S.dysg } \\
\text { alactia } \\
e\end{array}$ & 1.80 & 9.72 & 5.4 \\
\hline
\end{tabular}




\begin{tabular}{|c|c|c|c|c|c|c|c|c|c|c|c|c|c|c|c|c|c|c|}
\hline $\begin{array}{l}1 \\
5\end{array}$ & M & 56 & $\mathrm{H}$ & 15 & + & - & $\begin{array}{c}28 \\
6\end{array}$ & 1 & + & & 88 & - & + & MSSA & $M S S A$ & 0.50 & $\begin{array}{c}14.8 \\
9\end{array}$ & 29.8 \\
\hline $\begin{array}{l}1 \\
6\end{array}$ & $\mathrm{~F}$ & 86 & K & 2 & + & - & $\begin{array}{c}35 \\
5\end{array}$ & 2 & + & $\begin{array}{l}116 \\
000\end{array}$ & 77 & - & + & $\begin{array}{c}\text { S.dysg } \\
\text { alactia } \\
e\end{array}$ & & 0.90 & $\begin{array}{c}23.7 \\
0\end{array}$ & 26.3 \\
\hline $\begin{array}{l}1 \\
7\end{array}$ & M & 90 & $\mathrm{~K}$ & 15 & - & $+c$ & $\begin{array}{c}29 \\
1\end{array}$ & 2 & + & & 92 & - & - & $\begin{array}{l}\text { P.aeru } \\
\text { ginosa }\end{array}$ & & 3.40 & $\begin{array}{c}17.6 \\
8\end{array}$ & 5.2 \\
\hline $\begin{array}{l}1 \\
8 \\
\end{array}$ & $\mathrm{M}$ & 58 & $\mathrm{~K}$ & 2 & - & - & 54 & 1 & - & $\begin{array}{c}700 \\
00\end{array}$ & 91 & $\begin{array}{c}\mathrm{CP} \\
\mathrm{P}\end{array}$ & - & - & - & 4.80 & $\begin{array}{c}10.1 \\
1\end{array}$ & 2.1 \\
\hline $\begin{array}{l}1 \\
9\end{array}$ & $\mathrm{M}$ & 82 & $\mathrm{~K}$ & 4 & - & - & $\begin{array}{c}26 \\
2\end{array}$ & 1 & - & $\begin{array}{c}780 \\
00\end{array}$ & 90 & - & - & $\begin{array}{c}\text { S.dysg } \\
\text { alactia } \\
e\end{array}$ & $\nabla$ & 3.90 & 4.86 & 1.3 \\
\hline $\begin{array}{l}2 \\
0\end{array}$ & $\mathrm{M}$ & 52 & $\mathrm{H}$ & 3 & + & $+b$ & $\begin{array}{c}24 \\
3\end{array}$ & 3 & + & $\begin{array}{l}450 \\
000\end{array}$ & 83 & - & - & MSSA & MSSA & 0.60 & 3.59 & 6.0 \\
\hline $\begin{array}{l}2 \\
1\end{array}$ & $\mathrm{~F}$ & 43 & W & 3 & + & - & 6 & 1 & + & $\begin{array}{l}100 \\
000\end{array}$ & 92 & - & - & MSSA & - & 1.60 & 1.68 & 1.1 \\
\hline $\begin{array}{l}2 \\
2\end{array}$ & $M$ & 69 & $\mathrm{~K}$ & 1 & + & - & $\begin{array}{c}18 \\
8\end{array}$ & 1 & + & & 84 & - & - & E.coli & - & 2.00 & $\begin{array}{c}11,4 \\
0\end{array}$ & 5.7 \\
\hline $\begin{array}{l}2 \\
3\end{array}$ & $\mathrm{~F}$ & 66 & $\mathrm{~K}$ & 15 & - & - & 71 & 1 & & $\begin{array}{c}380 \\
0\end{array}$ & 82 & - & - & MSSA & - & 6.50 & 3,61 & 0.6 \\
\hline $\begin{array}{l}2 \\
4\end{array}$ & M & 62 & $\mathrm{~K}$ & 6 & - & - & $\begin{array}{c}10 \\
3\end{array}$ & 2 & 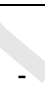 & $\begin{array}{c}120 \\
00\end{array}$ & 90 & - & - & $\begin{array}{c}\text { S.gord } \\
\text { onii }\end{array}$ & - & 0.40 & $\begin{array}{c}16,4 \\
9\end{array}$ & 41.2 \\
\hline $\begin{array}{l}2 \\
5\end{array}$ & $M$ & 62 & $\mathrm{~K}$ & 5 & + & & $\begin{array}{c}23 \\
0\end{array}$ & 4 & + & $\begin{array}{c}640 \\
00\end{array}$ & 94 & - & - & $\begin{array}{l}\text { H.parai } \\
\text { nfluenz } \\
\text { a }\end{array}$ & & 2.90 & 8,77 & 3.0 \\
\hline
\end{tabular}

a Cloxacilline, ${ }^{b}$ Amoxiciline/Clavulanate, ${ }^{c}$ Ceftriaxone, ${ }^{d}$ Clindamicine, ${ }^{e}$ Fluoroquinolones; W : Wrist ; H : Hip; K : Knee ;S: Shoulder; A: Ankle; CPP: Calcium Pyrophosphate Crystals SWBC= synovial white blood cell count, GT= Gram Stain, MSSA= Methicillin-sensitive Staphylococcus aureus MRSA=Methicillin-resistant Staphylococcus aureus 


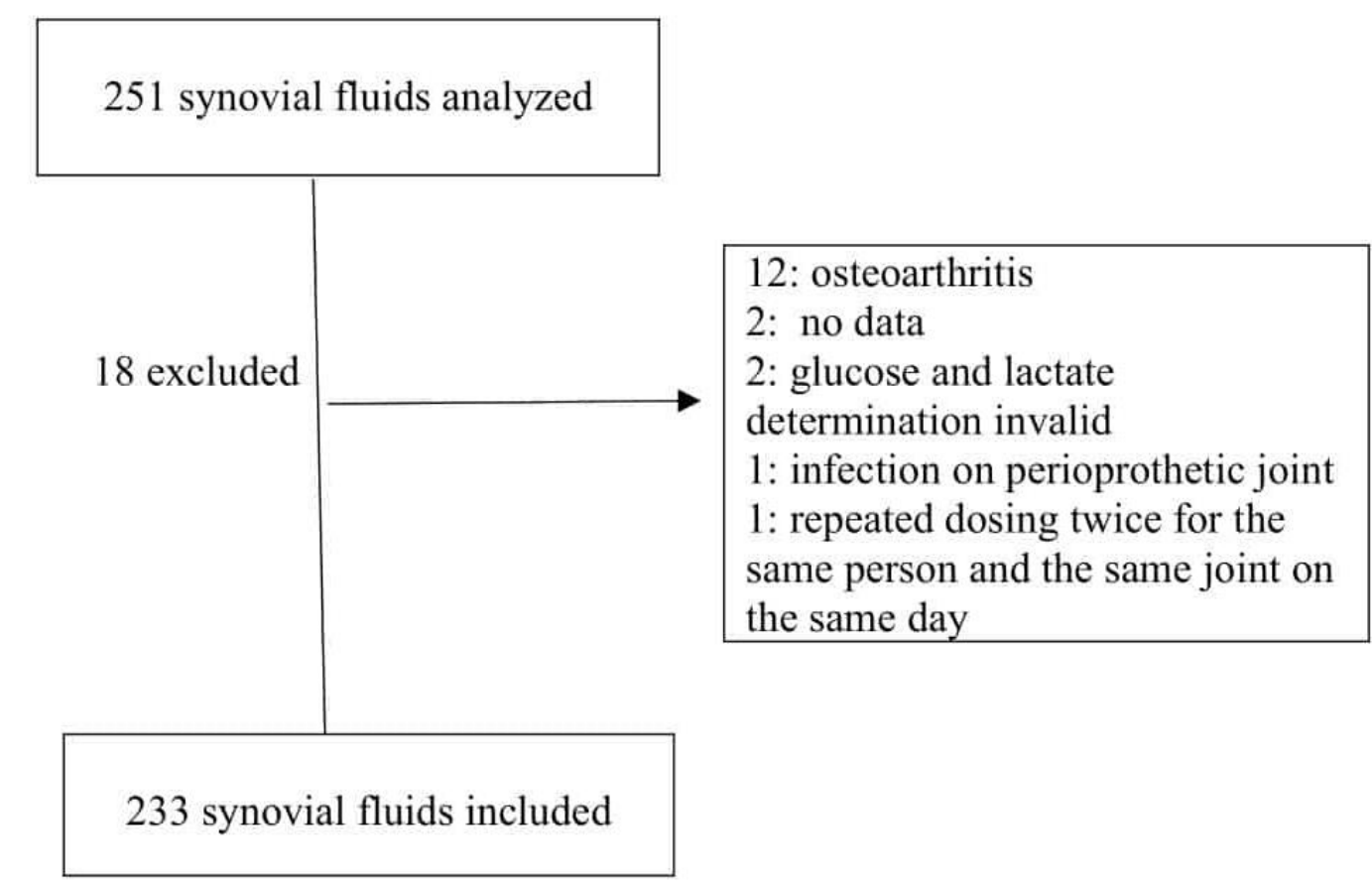

Figr-1 


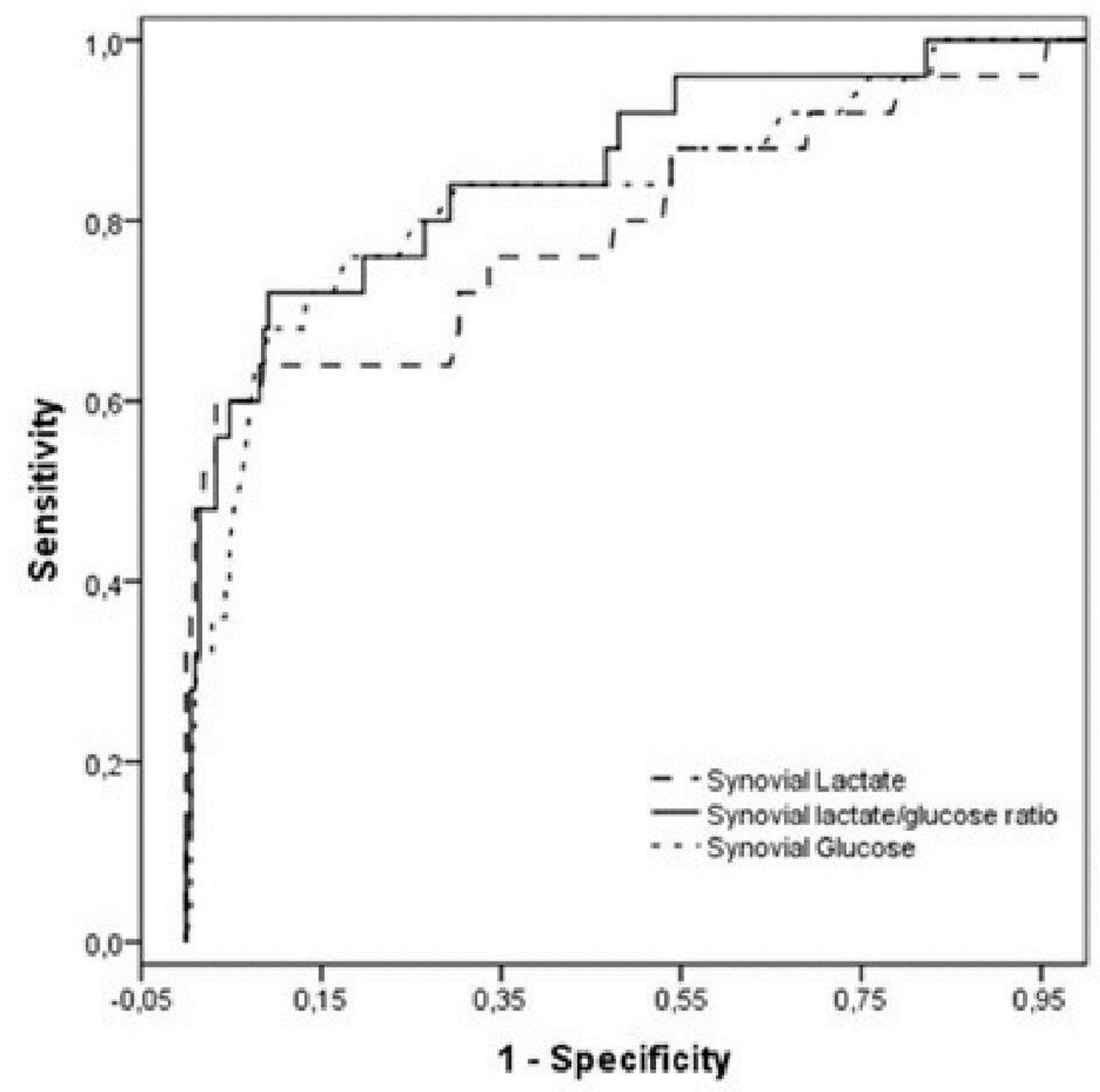

Figr-2 
Page 18 of 22 
Figr-3
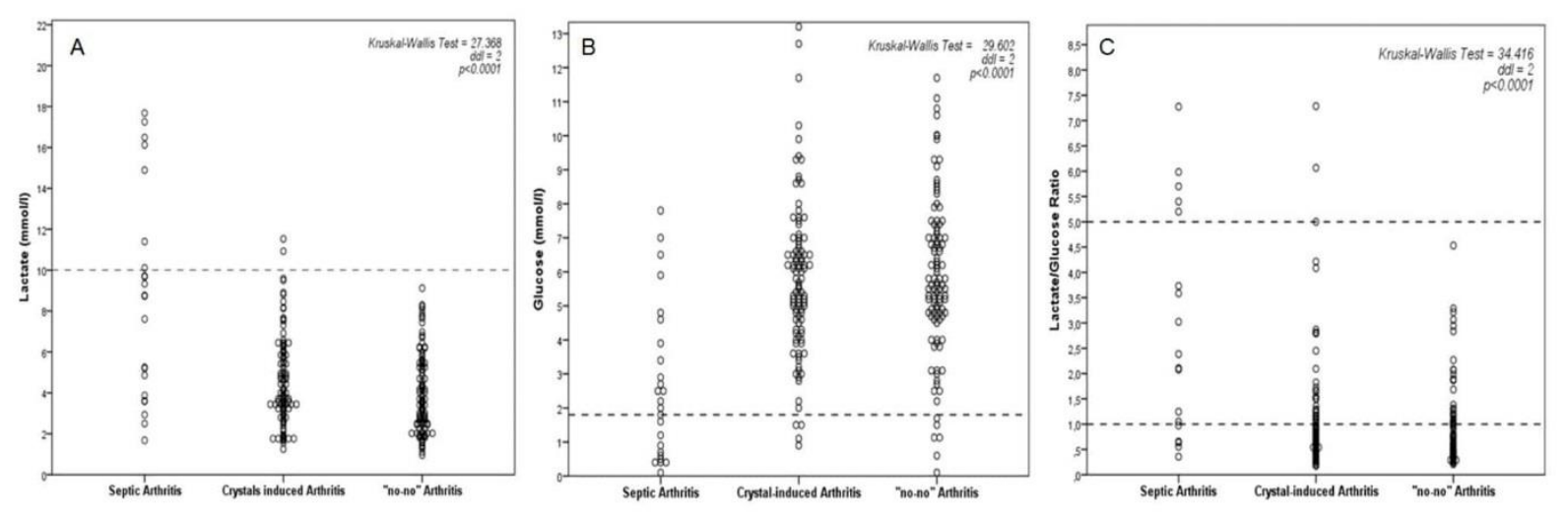
Table S1: Performance of CRP, Synovial white cells count or percentage of synovial polynuclear cells, synovial crystals detection, Gram stain or bacteriological culture in synovial fluid for diagnosis of septic arthritis.

\begin{tabular}{|c|c|c|c|c|c|c|}
\hline & AUC (CI95\%) & Cut-off & $\mathrm{Se}(\mathrm{Cl} 95 \%)$ & $\mathrm{Sp}(\mathrm{Cl} 95 \%)$ & $\mathrm{LR}+(\mathrm{Cl} 95 \%)$ & LR- (Cl95\%) \\
\hline CRP & $\begin{array}{l}0.705(0.581- \\
0.830)\end{array}$ & & & & & \\
\hline SWBC $\left(/ \mathrm{mm}^{3}\right)$ & $\begin{array}{l}0.737(0.595- \\
0.880)\end{array}$ & $\begin{array}{l}\geq \\
50000 \\
*\end{array}$ & $\begin{array}{l}72.2 \%(0.49- \\
0.88) \\
55.6 \%(0.34- \\
0.75) \\
\end{array}$ & $\begin{array}{l}80.0 \%(0.74-0.85) \\
90.1 \%(0.85-0.93)\end{array}$ & $\begin{array}{l}3.6(2.4-5.4) \\
5.6(3.1-10)\end{array}$ & $\begin{array}{l}0.35(0.16- \\
0.73) \\
0.49(0.29- \\
0.83) \\
\end{array}$ \\
\hline PNP (\%) & $\begin{array}{l}0.616(0.498- \\
0.735)\end{array}$ & $\geq 90 \%$ & $\begin{array}{l}59.1 \%(0.39- \\
0.77) \\
45.5 \%(0.27- \\
0.65)\end{array}$ & $\begin{array}{l}64.4 \%(0.57-0.71) \\
85.9 \%(0.80-0.90)\end{array}$ & $\begin{array}{l}1.7(1.1-2.5) \\
3.2(1.8-5.7)\end{array}$ & $\begin{array}{l}0.64(0.38- \\
1.06) \\
0.64(0.43- \\
0.93)\end{array}$ \\
\hline Gram Stain & $\begin{array}{l}0.556 \text { (0.404- } \\
0.707)\end{array}$ & - & $\begin{array}{l}16.7 \%(0.07- \\
0.36)\end{array}$ & $95.9 \%(0.92-0.98)$ & $4.0(1.3-12)$ & \begin{tabular}{|l|}
0.87 (0.73- \\
$1.04)$
\end{tabular} \\
\hline SF culture & $\begin{array}{l}0.841(0.716- \\
0.967)\end{array}$ & - & $\begin{array}{l}80.0 \%(0.61- \\
0.91)\end{array}$ & $95.7 \%(0.92-0.98)$ & $18.5(9.5-36)$ & \begin{tabular}{|l|}
$0.21(0.10-$ \\
$0.46)$ \\
\end{tabular} \\
\hline Blood culture & $\begin{array}{l}0.591(0.438- \\
0.745)\end{array}$ & - & $\begin{array}{l}28.0 \%(0.14- \\
0.48)\end{array}$ & $95.3 \%(0.91-0.98)$ & $6.0(2.4-15)$ & \begin{tabular}{|r|}
$0.760 .59-$ \\
$0.97)$
\end{tabular} \\
\hline
\end{tabular}

${ }^{*}$ Without crystal

Values in brackets are the corresponding 95\%-confidence intervals. AUC = Area under the curve, $\mathrm{Se}=$ sensitivity, $\mathrm{Sp}=$ specificity, $\mathrm{LR}+=$ positive likelihood ratio, $\mathrm{LR}-=$ negative likelihood ratio. $\mathrm{CRP}=\mathrm{C}$-reactive Protein,. $\mathrm{SWBC}=$ synovial white blood cell count. $\mathrm{PNP}=$ Percentage of neutrophil polynuclear. $\mathrm{SF}=$ synovial Fluid 
Table S2: Contingency Tables

Table S2 A. Synovial lactate contingency table

\begin{tabular}{|c|c|c|}
\hline & $\begin{array}{c}\text { Septic Arthritis } \\
(n=25)\end{array}$ & $\begin{array}{c}\text { Non Septic Arthritis } \\
(\mathrm{n}=208)\end{array}$ \\
\hline Lactate $>8.5 \mathrm{mmol} / \mathrm{L}$ & 15 & 7 \\
\hline Lactate $<8.5 \mathrm{mmol} / \mathrm{L}$ & 10 & 201 \\
\hline
\end{tabular}

Agreement $=92.7 \%$

\begin{tabular}{|c|c|c|}
\hline & $\begin{array}{c}\text { Septic Arthritis } \\
(\mathrm{n}=25)\end{array}$ & $\begin{array}{c}\text { Non Septic Arthritis } \\
(\mathrm{n}=208)\end{array}$ \\
\hline Lactate $>10 \mathrm{mmol} / \mathrm{L}$ & 10 & 2 \\
\hline Lactate $<10 \mathrm{mmol} / \mathrm{L}$ & 15 & 206 \\
\hline
\end{tabular}

Agreement $=92.7 \%$

\section{Table S2 B. Synovial glucose contingency table}

\begin{tabular}{|c|c|c|}
\hline & $\begin{array}{c}\text { Septic Arthritis } \\
(\mathrm{n}=25)\end{array}$ & $\begin{array}{c}\text { Non Septic Arthritis } \\
(\mathrm{n}=208)\end{array}$ \\
\hline Glucose $<1.8 \mathrm{mmol} / \mathrm{L}$ & 11 & 10 \\
\hline Glucose $>1.8 \mathrm{mmol} / \mathrm{L}$ & 14 & 198 \\
\hline Agreement $=89.7 \%$ & &
\end{tabular}

Agreement $=89.7 \%$

\begin{tabular}{|c|c|c|}
\hline & $\begin{array}{c}\text { Septic Arthritis } \\
(\mathrm{n}=25)\end{array}$ & $\begin{array}{c}\text { Non Septic Arthritis } \\
(\mathrm{n}=208)\end{array}$ \\
\hline Glucose $<1.0 \mathrm{mmol} / \mathrm{L}$ & 8 & 3 \\
\hline Glucose $>1.0 \mathrm{mmol} / \mathrm{L}$ & 17 & 205 \\
\hline
\end{tabular}

Glucose $>1.0 \mathrm{mmol} / \mathrm{L}$

Table S2 C. Synovial ratio lactate/ glucose contingency table

\begin{tabular}{|c|c|c|}
\hline$y$ & $\begin{array}{l}\text { Septic Arthritis } \\
(n=25)\end{array}$ & $\begin{array}{l}\text { Non Septic Arthritis } \\
(n=208)\end{array}$ \\
\hline Ratio > 1 & 20 & 59 \\
\hline Ratio $<1$ & 5 & 149 \\
\hline \multicolumn{3}{|l|}{ Agreement $=72.5 \%$} \\
\hline & $\begin{array}{l}\text { Septic Arthritis } \\
(n=25))\end{array}$ & $\begin{array}{l}\text { Non Septic Arthritis } \\
(n=208)\end{array}$ \\
\hline
\end{tabular}




\begin{tabular}{|l|c|c|}
\hline Ratio $>5$ & 12 & 4 \\
\hline Ratio $<5$ & 13 & 204 \\
\hline
\end{tabular}

